\title{
Biobriket Limbah Kulit Durian dengan Pencelupan pada Minyak Jelantah
}

\author{
Vita Efelina $^{\left.1^{*}\right)}$, Viktor Naubnome ${ }^{2)}$, Dessy Agustina Sari ${ }^{3 \text { ) }}$ \\ ${ }^{1)}$ Teknik Industri, Fakultas Teknik, Universitas Singaperbangsa Karawang \\ ${ }^{2}$ Teknik Mesin, Fakultas Teknik, Universitas Singaperbangsa Karawang \\ ${ }^{3)}$ Teknik Elektro, Fakultas Teknik, Universitas Singaperbangsa Karawang \\ *email: vita.efelina@staff.unsika.ac.id
}

Received: 28/08/2018; Revised: 26/09/2018; Accepted: 27/09/2018

\begin{abstract}
Abstrak
Kulit Durian memiliki potensi sebagai sumber energi terbarukan. Isu tersebut menjadi trending topic bidang energi sebagai solusi kelangkaan minyak bumi dan gas. Kandungan selulosa kulit durian mencapai $64,51 \%$ menjadi sumber energi biobriket. Kulit durian menjadi salah satu opsi karena komposisi kulitnya mencapai $60-75 \%$. Kulit durian ini mampu memperbesar densitas dan nilai ekonomis produk yang dihasilkan. Lalu, selain menggunakan kulit durian, peneliti juga melakukan penambahan minyak jelantah yang berperan sebagai pelapis biobriket agar produk sulit mengikat air, kadar air menjadi lebih rendah. Penggunaan lem kanji bertujuan untuk menjaga kerapatan briket sehingga produk tidak mudah hancur. Penelitian ini menggunakan proses karbonisasi kulit durian dengan suhu $600^{\circ} \mathrm{C}$ selama 60 menit. Karbon yang terbentuk digerus, lalu saring dengan pengayak ukuran 100 mesh. Nilai kalor paling tinggi sebesar 5673,367 kal/gram dengan perlakuan mencelupkan ke dalam minyak jelantah. Nilai kadar abu, kadar air, kadar uap dan fix carbon masing-masing adalah $12,90 \%, 9,37 \%, 17,79 \%$, dan $59,94 \%$.
\end{abstract}

Kata kunci: biobriket, karbonisasi, kulit durian, minyak jelantah

\begin{abstract}
Durian peels has the potential as a renewable energy source. The issue becomes trending topic of energy field as solution of oil and gas scarcity. The cellulose content reaches $64.51 \%$ to become a source of energy biobricket. Utilization of durian peels to be one option with the composition of the peels reaches $60-75 \%$. This supporting material can increase the density and economic value of the product. Then, the addition of cooking oil acts as a briquette coating to make the product difficult to bind water, the water content becomes lower. The use of adhesives kanji glue intended to maintain briquette density so that the product is not easily destroyed. This research uses carbonization process with operating condition for water durian peels is $600^{\circ} \mathrm{C}$ for durian peels each for 60 minutes. The formed carbon is crushed, then strain it with a sieve of 100 mesh. The highest calorie value was $5673,367 \mathrm{cal} / \mathrm{g}$ with a dipping treatment into cooking oil. The values of ash, moisture, vollatile matter and fix carbon were $12,90 \%, 9,37 \%, 17,79 \%$ and $59,94 \%$ respectively.
\end{abstract}

Keywords: biobriket, carbonization, cooking oil, durian peels,

\section{PENDAHULUAN}

Pada musim buah durian, volume sampah akan mengalami peningkatan yang signifikan dengan adanya kulit buah. Komposisi kulit buah durian mencapai 60$75 \%$, daging buah 20-35\%, dan bijinya 515\% (Sari et al., 2015). Kulit durian ini belum dimanfaatkan dengan baik dan hanya sebagai limbah yang menyebabkan pencemaran lingkungan, munculnya penyakit dan menurunkan nilai estetika kota. Limbah kulit durian dapat dimanfaatkan sebagai bahan baku briket. 
Briket merupakan salah satu solusi kelangkaan energi tak terbarukan (minyak dan gas bumi). Awal mula, manusia mengenalnya dengan nama arang, kayu dari hutan ditebang dan dibakar dalam tanah. Hal ini sudah ditinggalkan karena mengganggu keseimbangan alam (longsor, hutan gundul). Ide energi terbarukan muncul dengan memberdayakan limbah di segala sektor, misal pertanian (sekam padi), perairan (eceng gondok), pembangkit listrik (batu bara), dan rumah tangga (misalnya : kulit durian dan minyak jelantah). Penggunaan limbah organik ini memunculkan istilah biobriket.

Konversi kulit buah durian menjadi briket mampu memperbesar densitas, dan meningkatkan nilai ekonomis produk yang dihasilkan (Nuriana et al., 2013). Dalam penelitian ini telah dilakukan treatment pelapisan briket dengan minyak jelantah dengan tujuan briket terlapisi minyak sehingga produk sulit mengikat air dan kadar air menjadi lebih rendah (Septhiani dan Septiani, 2015). Bahan penunjang lainnya yang membantu produksi biobriket adalah bahan perekat berupa lem kanji. Perannya menjaga kerapatan briket sehingga produk tidak mudah hancur (Iriany et al., 2015).

Briket dengan mutu terbaik (SNI) belum ditemukan dan dikaji baik dari segi komposisi bahan baku, suhu dan waktu tempuh yang digunakan untuk proses karbonisasi. Penggunaan minyak jelantah sebagai agen penghambat adanya pengikatan air terhadap produk juga belum diteliti lebih lanjut. Tim peneliti merencanakan upaya diversifikasi energi terbarukan (usaha penganekaragaman produk) yaitu biobriket menggunakan proses karbonisasi. Sebagai studi awal, kajian diarahkan pada proses karbonisasi. Selanjutnya, pengembangan riset juga dilakukan dari segi bahan baku. Karbonisasi (destilasi kering) adalah suatu proses konversi zat organik menjadi karbon atau residu yang mengandung karbon melalui tahapan pembuatan arang. Proses berlangsung dengan membakar kulit sampel untuk menghilangkan kandungan air atau material yang tidak dibutuhkan oleh arang seperti hidrogen dan oksiden atau material yang menguap (Ridhuan dan Suranto, 2016). Riset ini merupakan kajian awal yang berfokus pada komposisi bahan baku yang digunakan dengan meninjau karakteristik produk (kadar air - abu, nilai fixed carbon, nilai kalor, kerapatan - densitas, lama nyala, dan kuat tekan), produk yang dihasilkan memenuhi standar output biobriket yaitu mempunyai kadar kalor sebesar $5600 \mathrm{kal} / \mathrm{g}$ (Hendra, 1999).

\section{METODE PENELITIAN}

a. Alat dan Bahan

Alat yang digunakan dalam penelitian ini adalah oven, saringan, furnace, mortar dan pengaduknya, desikator, cawan porselin, pisau, nampan, crusible, neraca digital, spatula, gelas ukur dan alat pengepres briket. Sedangkan bahan yang dibutuhkan dalam penelitian ini adalah kulit durian, tepung kanji, $\mathrm{H}_{2} \mathrm{O}$, dan minyak jelantah.

\section{b. Cara Kerja}

Cara kerja dalam penelitian ini adalah membuat arang kulit durian terlebih dahulu dengan cara memotong-motong sebesar 2 cm Kemudian memasukkan ke dalam oven dengan suhu $100^{\circ} \mathrm{C}$ selama satu jam. Setelah melakukan pengeringan menggunakan oven sampai massa stabil, kemudian melakukan proses pengabuan menggunakan furnace dengan suhu $600^{\circ} \mathrm{C}$ selama 60 menit. Kemudian melakukan penggerusan menggunakan mortar. Setelah 
itu, membuat tepung kanji dengan pelarut $\mathrm{H}_{2} \mathrm{O}$. Tepung kanji sebanyak $60 \mathrm{~g}$ dimasak menggunakan air matang dengan suhu sekitar $90^{\circ} \mathrm{C}$ sebanyak $600 \mathrm{~mL}$. Mengaduknya hingga tepung kanji berwarna bening. Mencampurkan tepung kanji sebanyak $10 \%$ dari berat massa total dengan arang kulit durian. Setelah proses pencampuran, selanjutnya melakukan proses pengepressan briket menggunakan alat press yang telah dibuat sebelumnya. Bentuk briket berupa silinder dengan tinggi kira-kira $4 \mathrm{~cm}$. Perlakuan dibuat berbeda dengan mencelupkan minyak jelantah dan tanpa mencelupkan minyak jelantah. Setelah itu melakukan pengeringan menggunakan suhu $60^{\circ} \mathrm{C}$ selama 60 menit.

\section{c. Analisis}

Analisis sampel briket menggunakan FTIR Prestige 21 Shimadzu Japan. Analisis proximate berupa kadar air, kadar abu, volatile matter (kadar uap), dan kadar karbon terikat (fixed carbon) menggunakan oven dan kalor menggunakan alat kalorimeter.

Tahap Perhitungan kadar air, kadar abu, volatile matter, fixed carbon dan kalori.

Untuk menghitung kadar air sampel menggunakan persamaan 1: (Haygreen dan Bowyer, 1989) :

$$
\text { Kadar air }=\frac{a-b}{a} \times 100 \%,
$$

dengan a adalah berat sampel awal, b adalah berat sampel akhir.

Untuk menghitung kadar abu juga hampir sama dengan menghitung kadar air, hanya saja proses nya yang berbeda. Pada proses pengabuan menggunakan furnace dengan suhu sekitar $600^{\circ} \mathrm{C}$ adalah menggunakan persamaan 2 berikut (ASTM D-2866-94) :

$$
\text { Kadar abu }=\frac{a-b}{a} 100 \%,
$$

dengan a adalah berat sampel awal, b adalah berat sampel akhir.

Untuk menghitung kadar uap (volatile matter) menggunakan persamaan 3 berikut ini :(ASTM D-5832-98)

$$
V m=\left(\frac{a-b}{a} \times 100 \%\right)-\text { kadarair }
$$

dengan a adalah berat sampel awal, b adalah berat sampel volatile.

Untuk menghitung kadar karbon terikat (fixed carbon) menurut (Standar Nasional Indonesia (SNI) 06-3730-1995 adalah sebagai berikut:

$$
\begin{aligned}
& \text { Fixed carbon }=100 \% \text { - (kadar air }+ \text { kadar } \\
& \text { abu + kadar uap }) \% .
\end{aligned}
$$

Besarnya nilai kalor total adalah besarnya perubahan suhu dikalikan dengan kapasitas kalor. Faktor koreksi didapat dari kawat dan benang yang digunakan dalam proses pembakaran. Nilai faktor terkoreksi merupakan nilai kalor total dikurangi dengan faktor koreksinya. Kemudian untuk mencari nilai kalor sampel adalah dengan cara membagi nilai kalor terkoreksi dengan berat sampel dalam satuan kal/g.

\section{HASIL DAN PEMBAHASAN}

Tabel 1. Hasil Uji Briket

\begin{tabular}{lll}
\hline Uji & $\begin{array}{l}\text { Tanpa } \\
\text { Minyak } \\
\text { Jelantah }\end{array}$ & $\begin{array}{l}\text { Dengan } \\
\text { Minyak } \\
\text { Jelantah }\end{array}$ \\
\hline Kadar Abu & $12,32 \%$ & $12,90 \%$. \\
Kadar air & $11,93 \%$ & $9,37 \%$. \\
Kadar uap & $16,38 \%$ & $17,79 \%$ \\
Fixed & $59,38 \%$ & $59,94 \%$ \\
carbon & & \\
Nilai Kalor & $5076,99 \mathrm{kal} / \mathrm{g}$ & $5655,23 \mathrm{kal} / \mathrm{g}$ \\
\hline
\end{tabular}


Berdasarkan Tabel 1, biobriket kulit durian dengan perekat tepung kanji mendapatkan hasil uji kadar abu sebesar $12,32 \%$. Variasi perlakuan dengan mencelupkan ke dalam minyak jelantah yang diharapkan dapat meningkatkan nilai kalor. Jika nilai kalor tinggi, maka akan dapat meningkatkan nilai laju pembakaran dan memudahkan penyalaan. Uji kadar abu setelah dicelupkan ke dalam minyak jelantah meningkat menjadi $12,90 \%$.

Selain melakukan uji kadar abu, dalam penelitian ini juga menguji kadar air dari briket kulit durian. Uji kadar air briket kulit durian tanpa pencelupan minyak jelantah dengan perekat tepung kanji menghasilkan $11,93 \%$. Setelah melakukan beda perlakuan dengan cara mencelupkan ke dalam minyak jelantah, kadar air cenderung mengalami penurunan kadar air menjadi 9,37\%. Perendaman briket dengan minyak jelantah memungkinkan briket terlapisi minyak sehingga lebih sulit untuk mengikat air. Kadar air yang rendah menyebabkan nilai kalor briket semakin baik.

Nilai kalor biobriket kulit durian tanpa melakukan pencelupan ke dalam minyak jelantah cenderung lebih sedikit nilai kalornya yaitu sekitar 5076,99 kal/g. Akan tetapi setelah melakukan pencelupan ke dalam minyak jelantah mengalami kenaikan kalor menjadi 5655,23 kal/g. Kadar zat menguap (volatile matter) adalah zat yang menguap sebagai hasil dekomposisi senyawa-senyawa yang masih terdapat di dalam arang selain air. Kandungan zat menguap yang besar menghasilkan asap yang banyak (Wijayanti, 2009).

Pengujian FTIR dilakukan untuk melihat dan mendeteksi gugus-gugus fungsi senyawa organik pada sampel. Spektrum FTIR arang kulit durian ditujukkan pada Gambar 1.

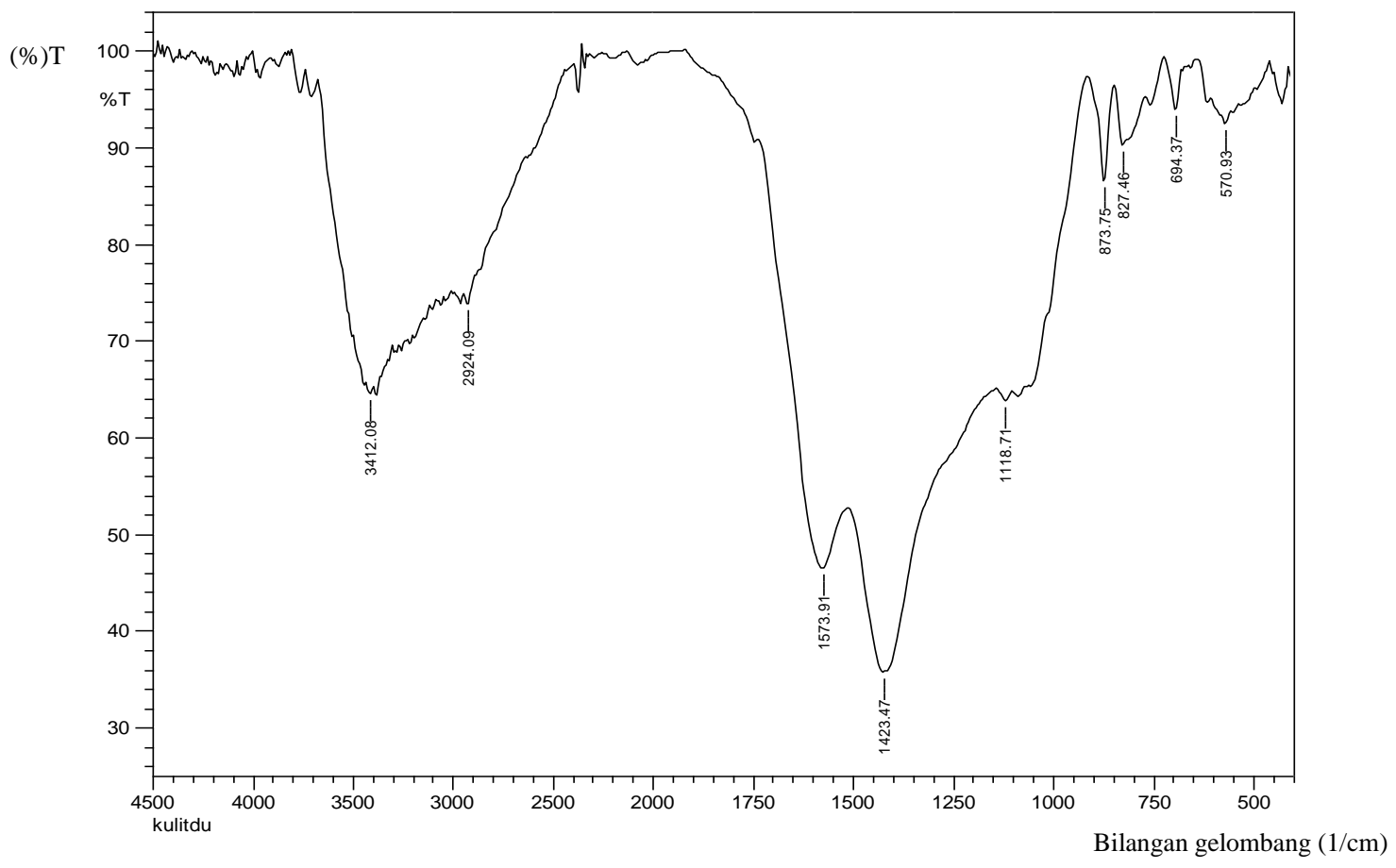

Gambar 1. Spektrum FTIR arang kulit durian 
Dari gambar 1 dapat dilihat bahwa spektrum FTIR arang dari kulit durian menunjukkan adanya vibrasi gugus fungsi $\mathrm{O}-\mathrm{H}, \quad \mathrm{C}-\mathrm{H}, \quad \mathrm{C}-\mathrm{N}, \quad \mathrm{C}=\mathrm{C}$ dari senyawa organik yang ditunjukkan dengan adanya pita serapan di daerah bilangan gelombang 500-4500 $\mathrm{cm}^{-1}$. Pada peak 694,37 $\mathrm{cm}^{-1}$ terdapat ikatan $\mathrm{C}-\mathrm{H}$ aromatik. Pada peak 827,46 dan $873,75 \mathrm{~cm}^{-1}$ terdapat ikatan C$\mathrm{H}$ alkena, pada peak $1118,71 \mathrm{~cm}^{-1}$ terdapat ikatan C-H amina, pada peak $1423,47 \mathrm{~cm}^{-1}$ terdapat ikatan $\mathrm{C}-\mathrm{H}$ alkana bending, pada peak $1573,91 \mathrm{~cm}^{-1}$ terdapat ikatan $\mathrm{C}=\mathrm{C}$ alkena, sedangkan pada peak $3412,08 \mathrm{~cm}^{-1}$ terdapat ikatan O-H asam karboksilat. (Sastrohamidjojo, 2001). Nilai transmitansi pada spektrum briket dari kulit durian tertinggi adalah $92,505 \%$ dan terendah adalah $35,839 \%$.

\section{KESIMPULAN}

Berdasarkan pembahasan yang dapat disimpulkan bahwa telah berhasil dibuat biobriket kulit durian dengan suhu karbonisasi $600^{\circ} \mathrm{C}$. Nilai kalor tertinggi adalah senilai $5655,23 \mathrm{kal} / \mathrm{g}$, dengan perlakuan mencelupkan ke dalam minyak jelantah. Nilai kalor tersebut sudah mencapai nilai minimal kalor dalam standar SNI yaitu min $5600 \mathrm{kal} / \mathrm{g}$. Nilai kadar abu, kadar air, kadar uap dan fix carbon masing-masing adalah 12,90\%, $9,37 \%, \quad 17,79 \%$, dan 59,94\%. Perlu dilakukan penelitian lebih lanjut tentang karakterisasi uji tekan, variasi komposisi, penambahan dengan bahan organik lain, atau variasi pengayakan serta variasi suhu karbonisasi.

\section{DAFTAR RUJUKAN}

American Society for Testing Material. 1990a. ASTM D 2866-94. Standard Test Method For Total ash Content of Activated Carbon. Philadelphia.
American Society for Testing Material. 1990b. ASTM D 5832-98. Standard Test Method For Total ash Content of Activated Carbon. Philadelphia.

Haygreen, J. G., \& Bowyer, J. L. (1989). Hasil Hutan dan Ilmu Кауи. (ID): Gajah Mada University Press. Yogyakarta.

Hendra, D. (1999). Bahan baku pembuatan arang dan briket arang. Litbang Hutan: Gunung Batu, Bogor.

Iriany, M. I., Abednego, F. S., \& Irvan. (2015). Pengaruh Perbandingan Massa Eceng Gondok Dan Tempurung Kelapa Serta Kadar Perekat Tapioka Terhadap Karakteristik Briket. J. Tek. Kim. USU., 5(1), 20-26.

Nuriana, W., Anisa, N., dan Martana (2013). Karakteristik Biobriket Kulit Durian Sebagai Bahan Bakar Alternatif Terbarukan," J. Teknol. Ind. Pertan., 23(1), 70-76.

Ridhuan, K., \& Suranto, J. (2016). Perbandingan Pembakaran Pirolisis Dan Karbonisasi Pada Biomassa Kulit Durian Terhadap Nilai Kalori. Turbo, 5(1), 50-56.

Sari, E., Praputri, E., Permadi, F., Susanti, O., Neno, Syafitri, E. (2015). Peningkatan Kualitas Biobriket Kulit Durian Dari Segi Campuran Biomassa, Bentuk Fisik, Kuat Tekan Dan Lama Penyalaan. Simposium Nasional RAPI XIV. FT UMS.

Sastrohamidjojo. (2001). Spektroskopi. Liberty: Yogyakarta.

Septhiani, S., \& Septiani, E. (2015). Peningkatan Mutu Briket dari Sampah Organik dengan Penambahan Minyak Jelantah dan 
Vita Efelina*, Viktor Naubnome, Dessy Agustina Sari

Biobriket Limbah Kulit Durian dengan Pencelupan pada Minyak Jelantah

Plastik High Density Polyethylene

(HDPE). J. Kim. Val., 1(2), 91-96.

Standar Nasional Indonesia. 1995. SNI 06-

3730-1995. Arang Aktif Teknis.

Jakarta: Badan Standardisasi

Nasional.

Wijayanti, D. S. (2009). Karakteristik

Briket Arang Dari Serbuk Gergaji

Dengan Penambahan Arang

Cangkang Kelapa Sawit. Teknologi

Hasil Hutan, Fakultas Pertanian

USU, Medan. 